\title{
Molecular mechanisms regulating follicular recruitment and selection
}

\author{
R. Webb ${ }^{1}$, B. K. Campbell ${ }^{2+}$, H. A. Garverick ${ }^{3}$, J. G. Gong', \\ C. G. Gutierrez $z^{4 *}$ and D. G. Armstrong ${ }^{4}$ \\ ${ }^{i}$ Division of Agriculture and Horticulture, School of Biological Sciences, University of \\ Nottingham, Sutton Bonington Campus, Loughborough, Leicestershire, LE12 5RD, UK; \\ 2Department of Obstetrics and Gynaecology, University of Edinburgh, 37 Chalmers Street, \\ Edinburgh, UK; ${ }^{3}$ Department of Animal Sciences, University of Missouri-Columbia, Columbia, \\ MO 65211, USA; and "Division of Development and Reproduction, Roslin Institute (Edinburgh), \\ Roslin, Midlothian EH25 9PS, UK
}

\begin{abstract}
Ovarian follicular growth and development is an integrated process encompassing both extraovarian signals, such as gonadotrophins and metabolic hormones, and intraovarian factors. Follicular development has been classified into gonadotrophin-independent and -dependent phases. In the latter, FSH provides the primary drive for follicular recruitment and $\mathrm{LH}$ is required for continued development of follicles to the preovulatory stage. A transient increase in circulating FSH precedes the recruitment of a group of follicles, and these recruited follicles are characterized by expression of mRNAs encoding P450scc and P450arom in granulosal cells. As follicles mature, there is a transfer of dependency from FSH to LH, which may be part of the mechanism(s) involved in selection of follicles for continued growth. Indeed, changes in the pattern of expression of mRNA for gonadotrophin receptors and steroid enzymes within follicular cells appear to be closely linked to changes in peripheral concentrations of gonadotrophins. The mechanism of selection of dominant follicles still requires clarification, but seems to be linked to the timing of mRNA expression encoding $\mathrm{LHr}$ and 3ß-hydroxysteroid dehydrogenase $(3 \beta \mathrm{HSD})$ in granulosal cells. Additional intraovarian systems, including the ovarian IGF and activin/inhibin systems, also exert a role. For example, it appears that the development of follicular dominance in cows is associated with the FSH-dependent inhibition of the expression of mRNA encoding insulin-like growth factor binding protein 2 (IGFBP-2) in granulosal cells. In conclusion, the integration of these endocrine signals and intraovarian factors within follicles determines whether follicles continue to develop and become dominant or are diverted into apoptotic pathways leading to atresia.
\end{abstract}

\section{Introduction}

Ovarian follicular growth is a developmental process during which follicles sequentially acquire a number of characteristics, each of which is an essential prerequisite for further development. The number of follicles that reach the ovulatory stage is regulated in a species- and breed-specific manner. However, many key mechanisms involved in this developmental process are still not understood, including (i) factors regulating the initiation of primordial follicle growth, (ii) control of antrum formation, (iii) mechanisms controlling follicle recruitment, selection and dominance, and (iv) the process of follicular atresia, the end-point of $>99 \%$ of follicles. However, molecular techniques have been used in domestic species over recent years to elucidate the patterns of expression of local follicular factors involved in this differentiative process.

* Present Address: Fac. Med, Vet. Zool, Universidad Nacional Autonome de Mexico, Mexico, IDF 04510.

'Present Address: School of Human Development, Queens Medical Centre, University of Nottingham, NG7 2UH, UK 
This review will concentrate on some primary factors involved in follicular recruitment, selection and dominance. Recent work investigating patterns in gene expression will be reviewed, as this has provided new insights into possible key mechanisms. A brief outline of the patterns of follicular growth and the relationship with gonadotrophins and metabolic hormones will be described, since the control mechanisms involve the interaction of systemic hormones and intrafollicular factors.

\section{Definitions of Stages of Follicular Development}

For this review the following generally accepted definitions have been used:

Recruitment-gonadotrophins stimulation of a pool of rapidly growing follicles.

Selection - a process whereby one or more of these recruited follicles are selected to continue to develop further.

Dominance - the mechanism(s) by which the dominant follicle(s), the number of which is speciesand breed-specific, undergoes rapid development in an environment where growth and development of other follicles are suppressed.

\section{Early Follicular Growth}

Growth of antral follicles to 2-4 mm in cattle and 1-2 $\mathrm{mm}$ in sheep is thought to be independent of gonadotrophins. Follicles can grow to this size in either the absence of gonadotrophins or the presence of very low concentrations of gonadotrophins (Campbell et al, 1995; Webb and Armstrong, 1998). However, recent studies investigating follicular growth patterns using transrectal ultrasonography show that small follicles (approximately $2 \mathrm{~mm}$ ) do exhibit waves of growth, as discussed later, suggesting that they are responsive to gonadotrophins.

\section{Gene expression in preantral and early antral follicles}

Gonadotrophin receptors. FSH receptor (FSHr) mRNA is localized specifically to both mural and cumulus granulosal cells and can be detected in follicles with only one or two layers of granulosal cells (Xu et al., 1995a). The role of the FSHr in preantral and early antral follicular growth is unknown. However, gonadotrophins do not seem to be required for the activation of bovine primordial follicles during culture of bovine ovarian cortical slices (Wandji et at. 1996). In contrast, late preantral follicles in culture show increased growth in response to FSH (Ralph et al., 1995). We have recently developed a system in which bovine preantral follicles can be sustained in long-term culture and proceed to develop an antrum (Gutierrez et al., 1997a). In this system follicles were responsive to the stimulatory effects of both FSH and a number of growth factors including IGF-I and EGF.

Expression of $\mathrm{LH}$ receptor $(\mathrm{LHr})$ mRNA is localized to thecal cells during the preantral and early antral stages of growth, and expression is detected when the theca interna forms around the granulosal cells (Xu et al., 1995a,b; Bao et al, 1997a).

Steroidogenic enzymes. mRNA for steroidogenic enzymes, cytochrome P450 side-chain cleavage

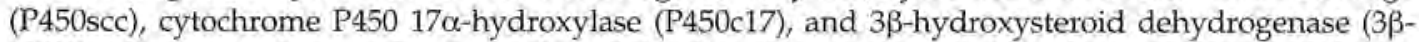
HSD) are expressed soon after formation of the theca interna. Expression of steroid acute regulatory protein (StAR) mRNA has also been detected in thecal cells (Bao et al., 1997b). Expression of mRNA for these enzymes tends to increase with growth of these early antral follicles (Xu et al., 1995a,b; Bao et al., $1997 \mathrm{a}, \mathrm{c})$. Cytochrome $\mathrm{P} 450$ aromatase (P450arom) is localized solely to granulosal cells, but expression cannot be found in non-recruited follicles $<4 \mathrm{~mm}$ in diameter. Apparently, the main steroid hormones produced by preantral and early antral follicles are pregnenolone, progesterone and androgen from 
thecal cells. This finding is in agreement with earlier work that measured in vitro steroid production and steroid concentrations in follicular fluid (see Webb and Gauld, 1987; Skyer et al., 1987).

The role of gonadotrophins in the induction of mRNA encoding gonadotrophin receptor and steroidogenic enzymes in preantral and early antral follicles is unknown. However, mRNA expression of FSHr in granulosal cells and expression of $\mathrm{LHr}, \mathrm{P} 450 \mathrm{scc}$ and P450c17 in thecal cells was not different in follicles $<4 \mathrm{~mm}$ in diameter in heifers with normal oestrous cycles compared with heifers in which follicles were arrested at approximately $4 \mathrm{~mm}$ in diameter due to $\mathrm{GnRH}$ agonist inhibition of FSH and LH secretion (H. A. Garverick, J. G. Gong, B. Baxter, D. G. Armstrong, B. K. Campbell and R. Webb, unpublished).

\section{Waves of Follicular Growth in Cattle and Sheep}

Two or three major phases of growth of large follicles occur during the bovine oestrous cycle, and the ovulatory follicle is selected at about 3 days before ovulation (see Ginther et al., 1996; Webb and Armstrong, 1998), Each wave of follicular development is characterized by the simultaneous emergence of medium-sized ( $>4-8 \mathrm{~mm}$ in diameter) follicles from a pool of smaller follicles. A dominant follicle emerges and continues to develop, while the others undergo atresia. The dominant follicle remains dominant for a few days, until it too becomes atretic and regresses, to be replaced within approximately 5 days by the next dominant follicle from the next follicular wave. If luteal regression takes place, the dominant follicle, free from the restrictive hormonal milieu imposed by the corpus luteum upon the hypothalamus-pituitary gland, will continue to develop (up to $20 \mathrm{~mm}$ in diameter) and will trigger the hormonal cascade leading to ovulation. Follicular waves appear to be constitutive, because they are present before puberty, throughout most of pregnancy and during the post-partum period, as well as during the oestrous cycle (Ginther et al., 1996; Webb and Armstrong, 1998).

In sheep, transrectal ultrasonography has proved more difficult to perform and interpret than in cattle because of problems of anatomical access and the smaller size and greater number of ovulatory follicles. Although evidence from both histological and ink marking studies support the occurrence of follicular waves (see Campbell et al., 1995), a number of studies using ultrasonography have reported random emergence of ovulatory-sized follicles throughout the sheep oestrous cycle (Schrick et al., 1993; Ravindra and Rawlings, 1997). Recent results, using the ovarian autotransplant model during seasonal anoestrus (Souza et al., 1996) and during the follicular (Souza et al., 1997a,b) and luteal (Souza et al., 1998) phases of the oestrous cycle, indicate that large antral follicles in sheep exhibit wave-like cycles (Fig. 1). All of these studies indicate that there is a period of functional dominance characterized by high oestradiol and inhibin A secretion, shorter than the period of morphological dominance, although dominant follicles are not the only source of inhibin A. Therefore, in sheep, follicular size alone is not an adequate parameter to assign dominance.

The overall pattern of follicle turnover in sheep during the luteal phase appears to be similar to that in cows, but there are clear species differences. In sheep, the wave interval is just 4-5 days, perhaps reflecting the smaller diameter of the dominant follicle, so that the ovulatory wave in sheep is likely to be either the third or the fourth, rather than either the second or the third, as in cattle. Furthermore, sheep can have more than one dominant follicle per wave, depending on the ovulation rate of the breed (Fig. 1), compared to usually one dominant follicle per wave in cows, indicating that follicular dominance is not so intense in sheep (Driancourt et al., 1991).

\section{Follicular Waves Associated with Patterns of Hormone Secretion}

Although it is clear that waves of dominant follicle development occur in both sheep and cattle, the endocrine and local mechanisms associated with this pattern of development have not been fully elucidated. It is well established, in both cattle (Adams et al., 1992) and sheep (Figs 1 and 2), that the emergence of a follicular wave is preceded by a transient increase in FSH and that the secretion of $\mathrm{FSH}$ is regulated by oestradiol and inhibin (Campbell et al., 1995). During the first follicular wave 

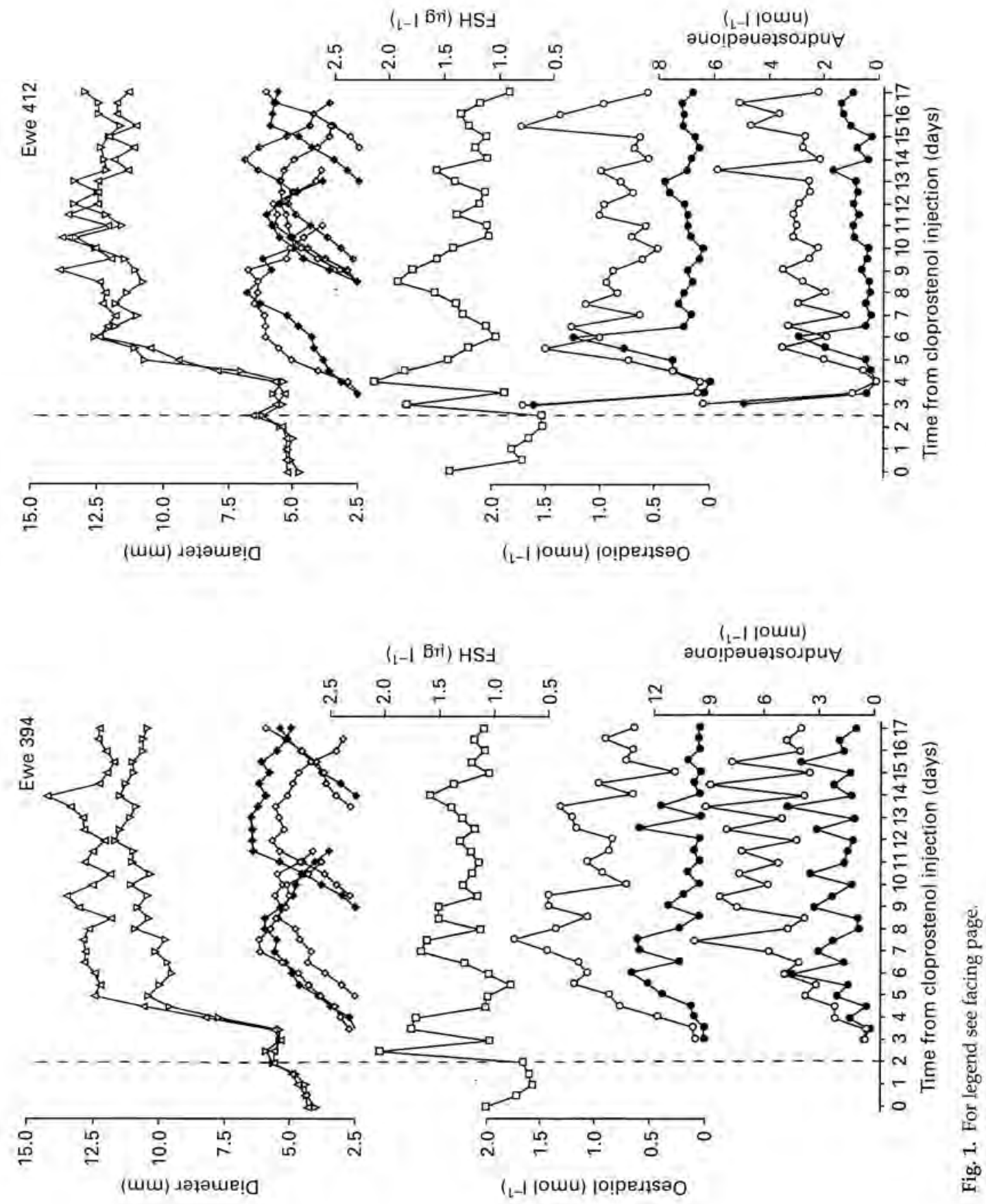


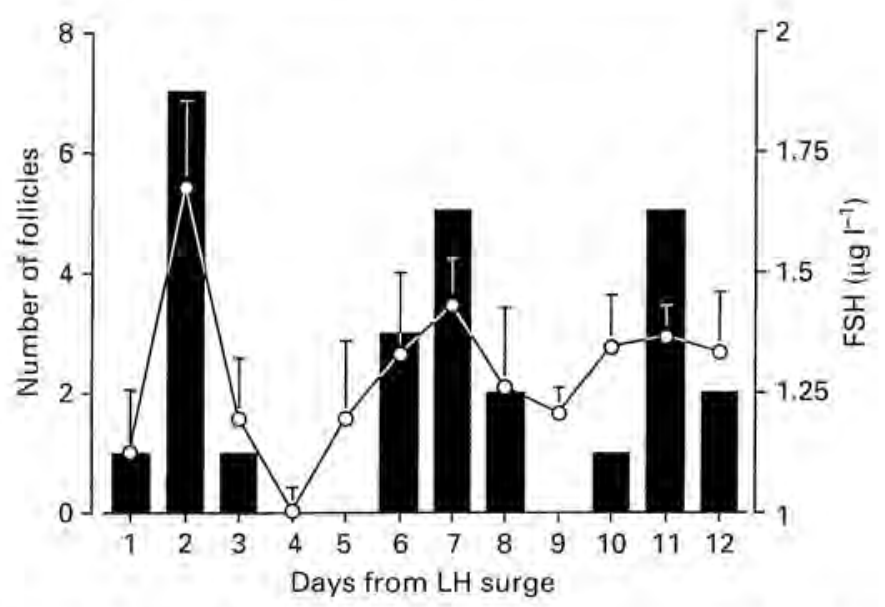

Fig. 2. Relationship between emergence of dominant follicles (solid bars) and mean concentration of FSH (open circles) in jugular venous blood ( \pm SEM, $n=5$ ) during the luteal phase of the ovine oestrous cycle. Adapted from Souza et al. (1998).

there is compelling evidence to support this explanation: secretion of both oestradiol (Knight, 1996; Souza et al, 1997a, 1997b, 1998) and inhibin A (Souza et al, 1997b, 1998) are positively related to follicular growth and inversely related to FSH. However, over subsequent waves, these relationships are less evident. Ovarian oestradiol secretion is dependent on both the presence of a large oestrogenic follicle in the ovary and appropriate LH stimulation (Campbell et al., 1995).

During the first follicular wave, LH pulse frequency is high and ovarian oestradiol secretion reflects this. However, during subsequent follicular waves $\mathrm{LH}$ pulse frequency declines as a result of luteal progesterone. Hence secretion of oestradiol no longer predicts the secretory capacity of the dominant follicle accurately (Souza et al., 1998). Indeed, wave 2 and 3 dominant follicles in sheep secrete the same amount of androstenedione, but less oestradiol, when challenged with LH. Therefore, it seems likely that a period of exposure to high frequency LH pulses is required before follicles acquire the ability to secrete normal amounts of oestradiol (Souza et al., 1998). As indicated, in contrast to oestradiol, inhibin A, measured in the sheep autotransplant model, is not solely derived from the dominant follicle(s) and is secreted in relatively high and constant amounts throughout the luteal phase. Thus the contribution of multiple follicles to ovarian secretion of inhibin A explains the lack of association between inhibin A and development of the dominant follicle during the mid-late luteal phase. However, as inhibin A secretion remains high during this phase of the ovarian cycle, when oestradiol secretion is low, it appears that inhibin $\mathrm{A}$ is the major regulator of FSH during the mid-late luteal phase. Thus, although it is clear that oestradiol and inhibin A control FSH secretion during the first follicular wave, the precise regulation of the FSH fluctuations associated with waves 2 and 3 awaits studies on the pattern of secretion of dimeric inhibin B.

We have recently developed an experimental model to investigate the relative importance of FSH and LH during different stages of follicular development. In this model, heifers are

Fig. 1. Dynamics of ovulatory follicles and/or corpus luteum (triangle) and dominant follicles (diamonds) from the three waves of follicular development during the luteal phase (top panel) and concentration of FSH (squares) in jugular venous plasma and concentration of oestradiol and androstenedione in ovarian venous plasma during the luteal phase from two representative ewes. The results show basal steroid concentrations (filled circles) and the steroid concentrations following a GnRH-challenge ( $250 \mathrm{ng}$ i.v.) (open circles). The dotted line indicates the time of the onset of the LH surge. Adapted from Souza et al. (1998). 


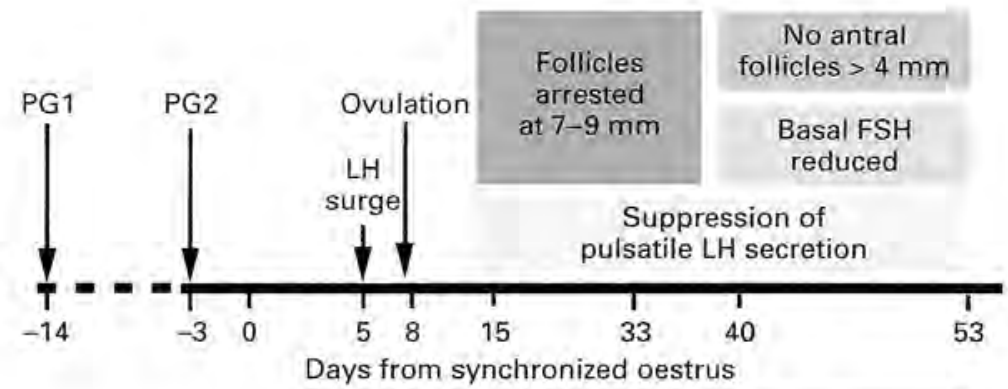

Continuous GinRHa (Buserelin). infusion $\left(2.5 \mathrm{ng} \mathrm{hr}^{-}\right)$

Fig. 3. Schematic summary of ovarian follicular dynamics, as measured by ultrasound per rectum, and association with patterns of gonadotrophin secretion in heifers treated with a GnRH agonist. Two injections of prostaglandin $F_{3 i t}$ (PG1 and PG2) were given to synchronize oestrous cycles. Note that growth was arrested initially at $7-9 \mathrm{~mm}$ diameter and then at $<4 \mathrm{~mm}$ in diameter.

continuously infused with GnRH agonist (Fig. 3). We found that the growth of follicles is arrested at 7-9 $\mathrm{mm}$ in diameter when pulsatile LH secretion is suppressed (Gong et al., 1995, 1996). When the secretion of basal FSH was also reduced, no antral follicles $>4 \mathrm{~mm}$ in diameter were observed (Gong et al, 1996). Using this model in conjunction with FSH, LH, or LH and FSH infusion, we have shown that FSH is initially required for the development of gonadotrophin responsive follicles (Campbell et al., 1995, 1998a; Gong et al., 1997). However, large antral follicles can transfer their dependence on gonadotrophins from FSH to LH (Campbell et al., 1995; Gong et al., 1996b). Furthermore, adequate LH pulsatile support appears to be required to maintain the ovulatory competence of the preovulatory follicles under decreased FSH concentrations (Campbell et al., 1995a). Indeed increased pulsatile secretion of $\mathrm{LH}$ has also been associated with the extended lifespan of dominant follicles (Sirois and Fortune, 1990). How do these changes in patterns of hormone release and follicular growth correlate with changes within the follicles themselves?

\section{Expression of mRNA for Gonadotrophin Receptors and Steroidogenic Enzymes during Follicular Growth}

\section{Gene expression during recruitment}

In cattle, follicular recruitment is generally thought to be gonadotrophin dependent and is considered to occur when follicles are stimulated to grow beyond $4 \mathrm{~mm}$ in diameter. Recruitment is also characterized by initiation of growth of a cohort of up to seven follicles that continue to grow to $8-9 \mathrm{~mm}$ in diameter. Thereafter usually one follicle in the cohort diverges rapidly from the others and continues to mature.

Gonadotrophin receptors. FSHr and LHr remain localized to granulosal and thecal cells, respectively, during recruitment and growth of the cohort (Fig. 4; Xu et al., 1995a,b; Bao et al., $1997 \mathrm{a}, \mathrm{c})$. During this time there is little change in expression of mRNA encoding FSHr and $\mathrm{LHr}$ (Table 1).

Steroidogenic enzymes. The initiation of simultaneous mRNA expression of P450scc and P450arom in granulosal cells of most follicles of $4-6 \mathrm{~mm}$ in diameter is associated with follicular recruitment in cattle (Xu et al., 1995a,b; Bao et al., 1997a). During later stages when the recruited follicles reach 

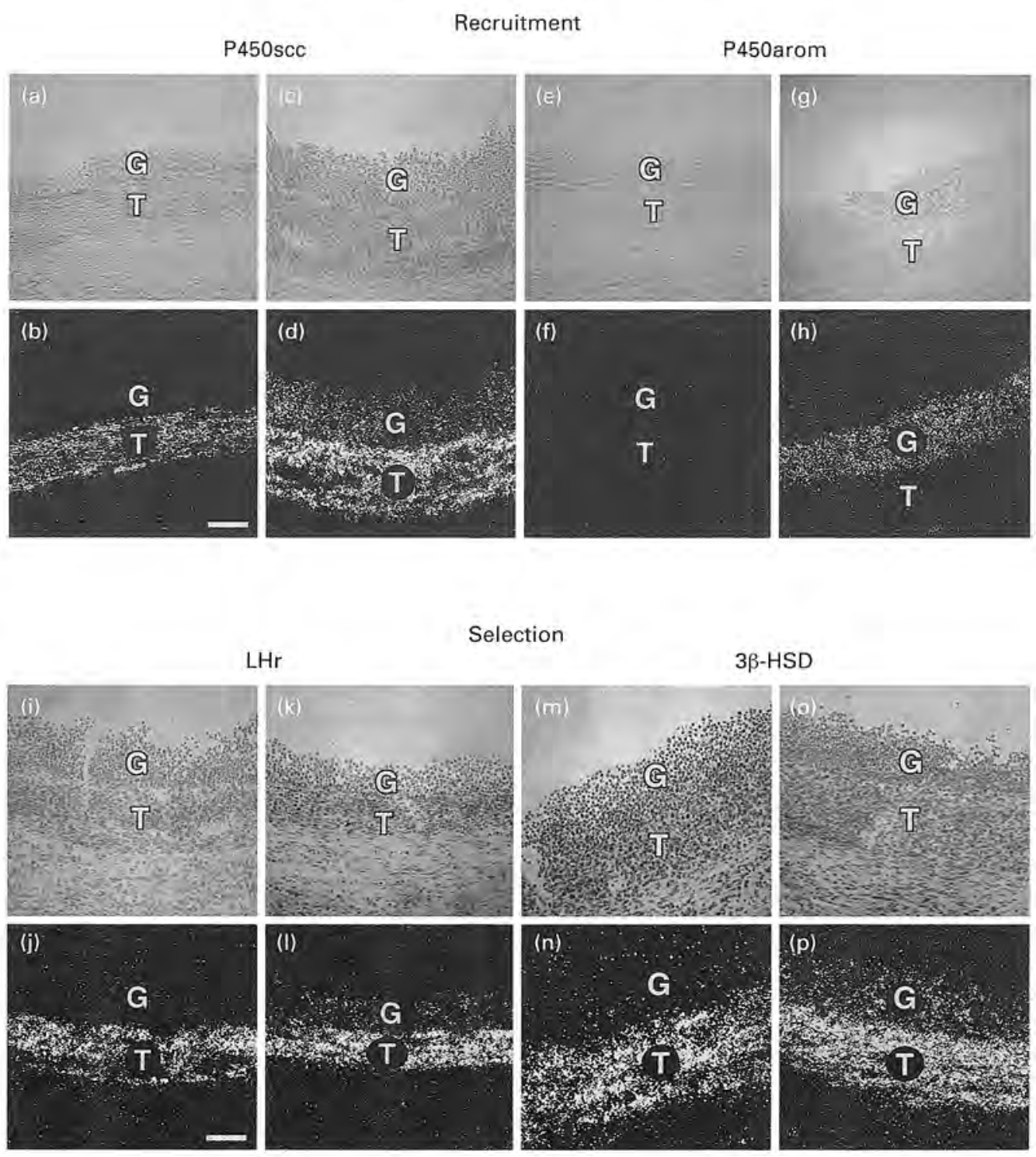

Fig. 4. In situ hybridization of luteinizing hormone receptor (LHr) and steroidogenic enzymes, cytochrome P450

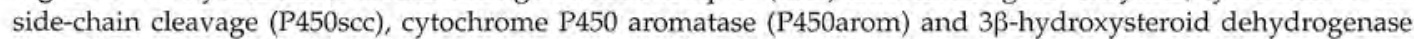
(3ß-HSD) mRNAs in cryosections of bovine ovarian follicles collected around the times of recruitment and selection of follicles during the first follicular wave. (a,b) Bright- and dark-field views of a 5 mm healthy follicle with no specific hybridization of P450scc in granulosal cells (not recruited). (c,d) Bright- and dark-field views of a healthy $6 \mathrm{~mm}$ recruited follicle collected at $24 \mathrm{~h}$ with specific hybridization for P450scc in both thecal and granulosal cells. (e,f) Bright- and dark-field views of a $5 \mathrm{~mm}$ healthy follicle with no specific hybridization of P450arom in granulosal cells (not recruited). $(\mathrm{g}, \mathrm{h})$ Bright- and dark-field views of a healthy $6 \mathrm{~mm}$ recruited follicle collected at $24 \mathrm{~h}$ with specific hybridization of P450arom in both thecal and granulosal cells. (i,j) Brightand dark-field views of a healthy $5 \mathrm{~mm}$ follicle with hybridization of LHr localized to thecal cells. (k,1) Brightand dark-field views of a $9 \mathrm{~mm}$ healthy follicle with specific hybridization of LHr to both thecal and granulosal cells. $(\mathrm{m}, \mathrm{n})$ Bright- and dark-field views of a $4 \mathrm{~mm}$ healthy follicle with specific hybridization of $3 \beta-H S D$ localized to thecal cells. (o,p) Bright-and dark-field views of a $9 \mathrm{~mm}$ healthy follicle with hybridization of $3 \beta-$ HSD to both thecal and granulosal cells. G: granulosal cells; T: thecal cells. Scale bars represent $50 \mu \mathrm{m}$. 
Table 1. Expression of messenger RNA encoding gonadotrophin receptors and steroidogenic enzymes during recruitment and selection of bovine ovarian follicles

\begin{tabular}{|c|c|c|c|c|c|c|}
\hline & \multicolumn{2}{|c|}{ Not recruited ${ }^{a}$} & \multicolumn{2}{|c|}{ Recruited $^{\mathrm{a}}$} & \multicolumn{2}{|c|}{ Selected } \\
\hline & Granulosa & Theca & Granulosa & Theca & Granulosa & Theca \\
\hline \multicolumn{7}{|l|}{ Gonadotrophin receptors } \\
\hline FSH & + & - & + & - & ++ & - \\
\hline LH & - & + & - & + & $+^{*}$ & t+ \\
\hline \multicolumn{7}{|l|}{ Steroidogenic enzymes } \\
\hline P450scc & - & + & $t^{*}$ & + & t+ & ++ \\
\hline P450c17 & - & + & - & + & - & ++ \\
\hline P450arom & - & - & $+^{*}$ & - & + & - \\
\hline $3 \beta-\mathrm{HSD}$ & - & + & - & + & $t^{*}$ & + \\
\hline Sterofdogenic acute & & & & & & \\
\hline regulatory protein (StAR) & - & + & - & + & - & t+ \\
\hline
\end{tabular}

aifferences in the intensity of expression have not been tested between not recruited and recruited follicles.

- Indicates when mRNA expression is first detected.

+ or ++ denotes amount of expression.

6-9 mm in diameter, all follicles in the cohort express P450scc and P450arom mRNA in the granulosal cells. During this time some of the $4-5 \mathrm{~mm}$ follicles that were apparently recruited do not express P450scc and P450arom. The number of follicles that express P450scc and P450arom during the early stages of recruitment is similar to the number of follicles that continue growth during later stages of recruitment. Therefore, recruitment of follicles that continue growth beyond $4-6 \mathrm{~mm}$ in diameter may be associated with expression of mRNA P450scc and P450arom in granulosal cells (Table 1; Fig. 4).

Expression of P450scc and P450arom mRNA is likely to be important for continued growth, since all follicles that continue to grow beyond $4-6 \mathrm{~mm}$ in diameter, after the initial stages of recruitment, expressed mRNA for P450scc and P450arom (Bao et al., 1997c). It is at this stage of growth that follicles develop the capability to produce significant quantities of oestradiol. This is consistent with previous reports that follicles less than $5 \mathrm{~mm}$ in diameter do not produce oestradiol (Skyer et al., 1987). Induction of P450scc and P450arom mRNA is probably due to a transient increase in circulating FSH that precedes initiation of each wave of follicular growth (Adams et al., 1992; Fig. 4). LH may not be involved in follicular recruitment or mRNA P450scc and P450arom expression, since $\mathrm{LHr}$ mRNA is not detected in granulosal cells during recruitment. If $\mathrm{LH}$ is involved, the effect is likely to be an indirect one through stimulation of thecal androgen synthesis. In addition, follicles grow to 7-9 mm in diameter when LH, but not FSH, is inhibited (Fig 3; Gong et al., 1996).

\section{Gene Expression during Selection}

When the cohort of follicles in cattle reach $8-9 \mathrm{~mm}$ in diameter, there is rapid divergence whereby one follicle increases rapidly in size, becomes larger than the other follicles and becomes the dominant follicle (Ginther et al, 1996). Divergence of the selected follicle seems to occur about 36 to $48 \mathrm{~h}$ after initiation of a follicular wave. In cattle, divergence of the selected follicle appears to be

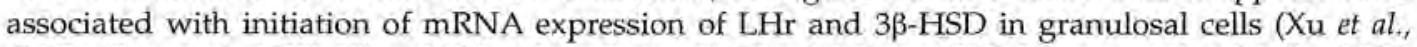
1995b; Bao et al.x 1997c; Fig. 4). Whether selection of the dominant follicle or granulosal cell mRNA

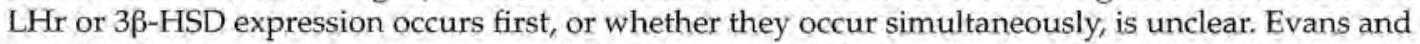
Fortune (1997) reported an increase in both size and oestradiol secretion in one follicle of the cohort

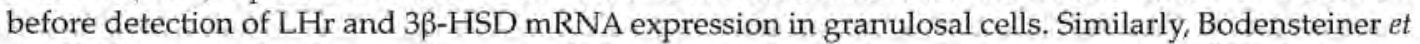
al. (1996) reported an increase in oestradiol concentration in the selected dominant follicle before an increase in the numbers of gonadotrophin receptors. Regardless, all dominant follicles express 
mRNA for LHr, 33-HSD and P450arom (Xu et al, 1995a; Bao et al., 1997a,c). However, in this study, the number of receptors for LH included those in the thecal cells as well as those in the granulosal cells. In addition, divergence (identification) of the selected follicle occurs when circulating concentration of FSH, which has been decreasing from shortly after recruitment, reaches its nadir. Thus, the follicle that is the most functionally developed can survive in an environment of decreasing FSH concentration. Hence the first follicle to develop LHr in granulosal cells would be able to respond to $\mathrm{LH}$, as well as FSH, and to survive in an environment unable to support the other follicles (Gong et al., 1996; Figs 3 and 4). In rodents, induction of the LHr in granulosal cells is dependent on the action of FSH and oestradiol (Segaloff et al., 1990). Thus, the follicle with the highest concentration of oestradiol would be the first follicle to develop LHr in the granulosal cells and hence, allow granulosal cells of the selected follicle to become responsive to LH, as well as FSH, and survive in the face of declining serum FSH.

Continued growth of selected follicles is generally accompanied by increased expression of gonadotrophin receptors, steroidogenic enzymes and StAR, and selected and dominant follicles have higher mRNA expression than subordinate and atretic follicles. Despite the increases in $\mathrm{mRNA}$ expression of follicles during development, selection probably cannot be determined by the differential mRNA expression of either LHr, P450scc, P450c17, 3ß-HSD or StAR in thecal cells, FSHr and P450arom in granulosal cells, or P450scc in granulosal and thecal cells (Table 1). This is because more than one follicle, of approximately the same size, expresses similar amounts of these mRNAs indicating that either the current techniques are too insensitive or selection depends on the expression of other upstream factors that remain to be determined.

\section{Gene Expression during Dominance and Atresia}

\section{Follicular dominance}

Dominant follicles continue to grow for a few days after selection. Expression of mRNA for the gonadotrophin receptors, steroidogenic enzymes and StAR generally increase in thecal and granulosal cells during the growing phase, and follicles produce greater amounts of oestradiol (Xu $e t$ al., 1995a,b; Bao et al., 1997a,c). Thus, dominant follicles acquire increased capability to produce steroids during their development, supporting previously published work investigating follicular steroid production (see Campbell et al., 1995; Webb and Armstrong, 1998). In addition, the patterns of mRNA expression are in agreement with previous work in sheep and cattle that has found that $\mathrm{LH}$ can support dominant follicle development. However, if the LH pulse frequency is too low, for example during the middle of the luteal phase, dominant follicle growth will not continue. After luteolysis, mRNA expression for P450scc, P450c17 and 3BHSD, but not P450arom, increases (Tian et al., 1995). Concurrently, follicular fluid concentrations of androstenedione and oestradiol increase, under the influence of increased pulsatile LH release. The significant increase in expression of mRNAs encoding the steroidogenic enzymes and follicular fluid steroid concentrations are likely due to increased pulse frequency of LH secretion during the preovulatory period (Campbell et al., 1995). The increase in $\mathrm{LH}$ pulse frequency may increase mRNA expression for the steroidogenic enzymes necessary for synthesis of androgen precursors for oestradiol production. Thecal cell production of androgens in cattle may be the rate-limiting step for follicular oestradiol production (Badinga et al., 1992), but the fact that the oestradiol:androgen ratio remains approximately one throughout the follicular phase in sheep (Campbell et al., 1990) would appear to make this unlikely unless there are key species differences.

\section{Follicular atresia}

If luteolysis does not occur during the growing phase of the dominant follicle, the fate is atresia. Expression of gonadotrophin receptor mRNAs, steroidogenic enzymes and StAR decrease rapidly with atresia, and a decline in expression occurs earlier than morphological signs of atresia are 
observed (Xu et al., 1995a,b). Atresia of dominant follicles appears to be initiated between days 4 and 6 in the non-ovulatory follicular wave. Expression of mRNAs for FSHr in granulosal cells, $\mathrm{LHr}$ in thecal cells, P450scc in granulosal and thecal cells, and P450c17 in thecal cells decreases markedly between days 4 and 6 of the follicular wave. Interestingly, expression of mRNAs for LHr and P450arom in granulosal cells is still high on day 6 , but declines by day 8 of the follicular wave (Xu et al., 1995a,b). Atresia of unselected follicles from the cohort appears to be similar to atresia of dominant follicles.

\section{Additional Extraovarian Regulators of Follicular Growth}

Although follicular development is primarily regulated by gonadotrophins, other systemic factors have been shown to alter follicular growth patterns. Pharmacological administration of recombinant $\mathrm{GH}$ increased the number of antral follicles without altering gonadotrophin concentrations (Gong et al., 1991; de la Sota et al., 1993; Gong et al,, 1993). Moreover, a reduction in GH and IGF-I concentrations after immunization of prepubertal heifers against GHRH inhibited the development of follicles $>7 \mathrm{~mm}$ in diameter (Cohick et al, 1996). However, pharmacological manipulation of GH concentration may not reflect its physiological action. Recently we demonstrated that flushing heifers (200\% maintenance of a low fibre diet) stimulated an increase in the number of small $(<4 \mathrm{~mm})$ follicles, despite reduced GH concentrations. However, there was high insulin concentration compared with controls (Gutierrez et al., 1997b) indicating that GH may not act directly to alter follicular development. Indeed, direct administration of $\mathrm{GH}$ into the ovarian artery did not stimulate ovarian steroid secretion in the autotransplanted sheep (Campbell et al., 1995) and the identification of follicular GH receptors has proved difficult (Lucy et al., 1993). GH may act through differential responses of IGF-I and insulin. IGF-I is a potent stimulator of steroidogenesis and proliferation of both granulosal and thecal cells in vitro (Campbell et al., 1996, 1998b; Gutierrez et al., 1997c). Insulin also stimulates proliferation and steroidogenesis of granulosal and thecal cells in vitro (Campbell et al., 1998b; Gutierrez et al., 1997d). The bioavailability of IGFs is regulated by their association with a family of specific IGFBPs which in turn are affected by nutrition (Webb and Armstrong, 1998). Hence, systemic metabolic factors can influence follicular recruitment and selection. However, in addition to this extraovarian IGF system there is also an intraovarian system that may function in concert to alter the response of follicles to gonadotrophins.

\section{Intraovarian Regulation of Follicular Growth}

A range of follicular growth factors are now known to be involved in the regulation of follicular growth, including the TGF- $\beta$ superfamily, FGFs, EGF and TGF $\alpha$ and cytokines as well as the IGFs. Many of the intraovarian growth factor signalling systems act through tyrosine kinase receptors that regulate granulosal and thecal cell differentiation in a coordinated manner through interaction with gonadotrophin-cAMP-stimulated mechanisms. The integration of the endocrine and intraovarian mechanisms provide the necessary signals that either stimulate follicular growth or divert the follicle into apoptotic pathways resulting in follicular atresia. This section will concentrate on components of two of the most intensively studied families, namely the IGF and activin-inhibin systems.

\section{Ovarian IGF system}

The IGF system, occupying a central position within the 'network' of intraovarian signals, includes the IGF ligands (IGF-I and -II), at least six IGF-binding proteins (IGFBP-1 to -6), type 1 and type 2 IGF receptors and specific IGFBP proteases. To date, expression of mRNAs encoding IGFBP-2 to -5 have been found in bovine follicles and expression of IGFBP-2, -4 and -5 in ovine follicles (Armstrong and Webb, 1997; Webb and Armstrong, 1998). 
Insulin-like growth factors $I$ and II. IGFs stimulate granulosal and thecal cell proliferation and differentiation and have been identified as follicular survival factors. There is considerable species variation in the patterns of mRNA expression of IGF ligands and BPs during folliculogenesis. We have detected the expression of mRNA encoding IGF-II in thecal tissue of bovine ovarian follicles (Armstrong and Webb, 1997) and a similar spatial distribution has been described in sheep (Perks et al., 1995). The expression of mRNA encoding IGF-I in ruminants remains controversial. Leeuwenberg et al. (1995) detected IGF-I mRNA in ovine granulosal and thecal tissue, and Yuan et al. (1998) detected IGF-I mRNA in bovine granulosal cells. In contrast, Perks et al. (1995) failed to detect the expression of mRNA encoding IGF-I in ovine follicles. Similarly, we were unable to detect expression of IGF-I mRNA in bovine follicles by in situ hybridization (Fig. 5). In support of this last observation we recently demonstrated that non-luteinized bovine granulosal cells do not produce IGF-I in serum-free cultures (Gutierrez et al., 1997c).

IGF-binding proteins. The bioactivity of IGFs are controlled by their association with IGFBPs. As with the IGFs, the spatial expression of these binding proteins within ovarian follicles is species specific (Armstrong and Webb, 1997). In cows (Armstrong et al., 1998) and sheep (Besnard et al., 1996), expression of mRNA encoding IGFBP-4 and -2 is restricted to thecal and granulosal tissue, respectively. The spatial and temporal patterns of expression of mRNA encoding components of the IGF system in the bovine follicle are summarized in Figs 5 and 6.

In ovarian cell culture systems examined so far, IGFBPs attenuate the actions of IGFs (Mason et al., 1992; Monget et al., 1993; Spicer et al., 1997). A decrease in follicular IGFBP production would therefore be expected to enhance the biological activity of locally produced IGFs, resulting in increased follicular response to gonadotrophins. The observed decrease in the concentration of IGFBP-2, -4 and -5 in follicular fluid during the development of dominance supports this hypothesis (Armstrong et al., 1996). In cows (Armstrong et al., 1998) and sheep (Besnard et al., 1996) the decrease in IGFBP-2 concentration in follicular fluid during follicular growth was shown to be due to a loss of expression of mRNA encoding IGFBP-2 in granulosal cells in dominant follicles. Using serum-free bovine granulosal cell cultures, we have shown that FSH, at physiological concentrations, inhibits expression of mRNA encoding IGFBP-2 (Armstrong et al., 1998). These results indicate that a key feature in the development of follicular dominance in cattle is the FSH-dependent inhibition of the expression of mRNA encoding IGFBP-2 in granulosal cells (Fig. 6). The resultant increase in IGF bioactivity in these follicles would increase FSH responsiveness of their granulosal cells.

\section{Activin-inhibin system}

The TGF- $\beta$ superfamily comprises a range of proteins, including members of the activin-inhibin system, with the potential to act as intraovarian regulators. mRNAs encoding TGF- $\beta$ are expressed in thecal cells from both mammalian and non-mammalian species (Armstrong and Webb, 1997). In cows, TGF $\beta$ s inhibit granulosal and thecal cell proliferation while enhancing gonadotrophinstimulated steroidogenesis (Roberts and Skinner, 1991).

Inhibin-activin family. Expression of mRNA for members of the inhibin-activin family appears to be initiated in a sequential and co-ordinated way during early follicle development. In sheep, mRNA expression of B-inhibin-activin subunit appears concomitant with expression of $\mathrm{FSHr}$ at 1-2 layers of cuboidal granulosal cells followed by inhibin $\alpha$-subunit and follistatin at more than 2-4 layers of granulosa cells and finally $\beta A$-inhibin-activin subunit during early antral development (Eckery et al., 1996). As ovine follicles progress from small $(<2 \mathrm{~mm})$, to medium-sized $(2-4 \mathrm{~mm})$ and to large ( $>4 \mathrm{~mm}$ ) there is a progressive increase in $\mathrm{P} 450 \mathrm{c} 17$ expression in the theca and inhibin $\alpha$ and $\beta A$-subunit, LH-receptor and P450arom expression in the granulosal cells. In contrast expression for $\beta B$-inhibin-activin subunit in granulosal cells and $\mathrm{LH}$ receptor in thecal cells remains relatively constant (B. K. Campbell, L. M. Harkness, D. G. Armstrong, H. A. Garverick and R. Webb, 

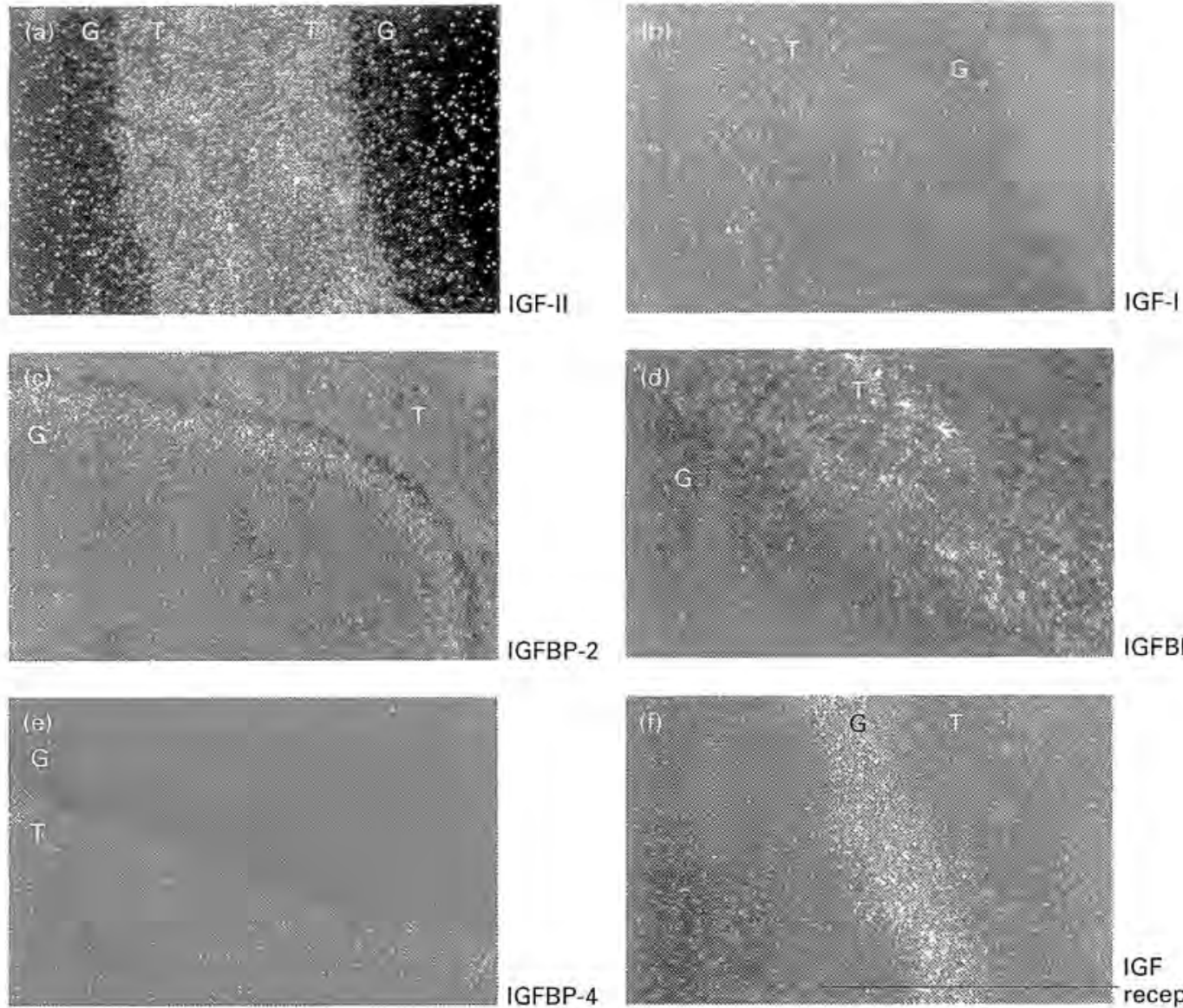

IGF GFBP-4

receptor
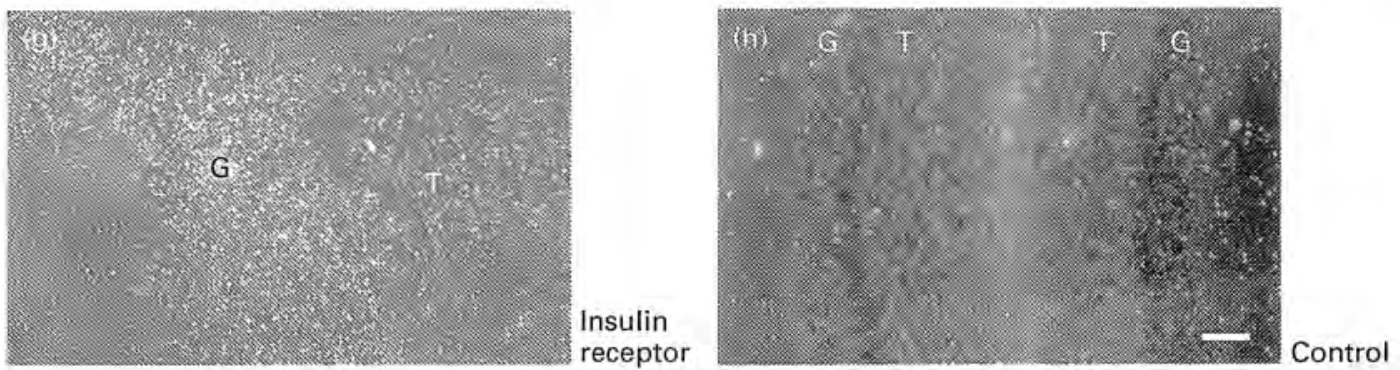

Fig. 5. In situ hybridization of mRNAs encoding (a) IGF-II, (b) IGF-I, (c) IGFBP-2, (d) IGFBP-3, (e) IGFBP-4, (f) type 1 IGF receptor, $(\mathrm{g})$ insulin receptor and typical control section probed with sense IGF-II RNA in bovine follicles. G and T represent granulosal and thecal cells, respectively. Scale bar represents $100 \mu \mathrm{m}$.

unpublished). The association between P450arom and $\beta A$-subunit expression is particularly interesting as both these factors are expressed precociously in medium-sized follicles in sheep carrying the $\mathrm{FecB}$ gene (Fig. 7). This is a major gene that results in a marked increase in prolificacy associated with the ovulation of significantly more follicles at a smaller size. The correlation between 


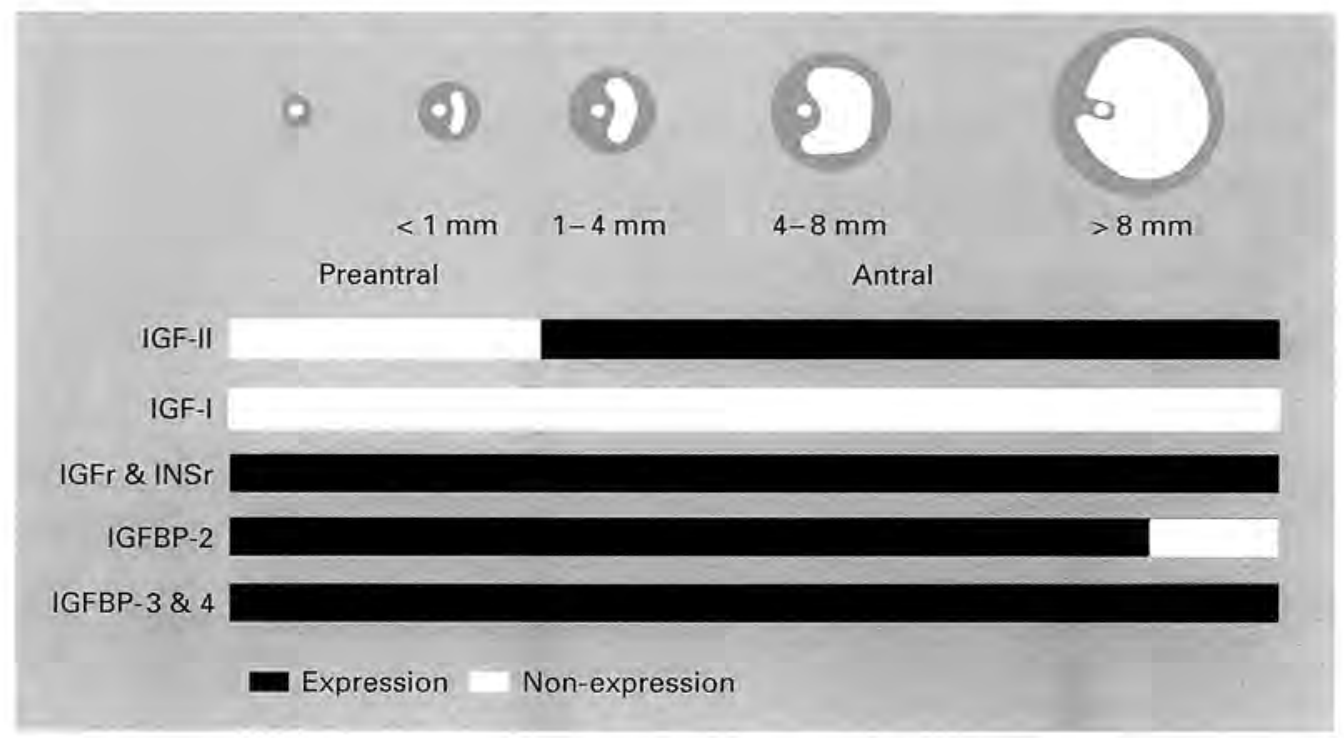

Fig. 6. The relationship between the temporal patterns of expression of mRNAs encoding components of the IGF system during bovine follicular development.

(a)

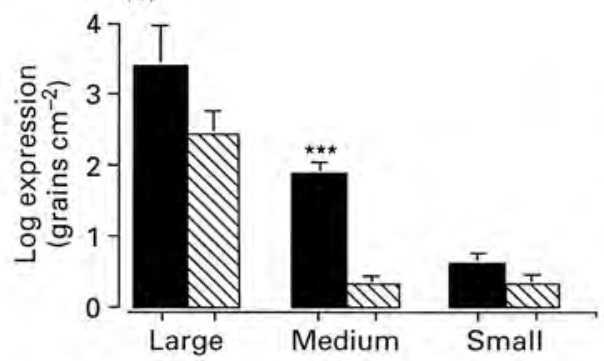

(b)

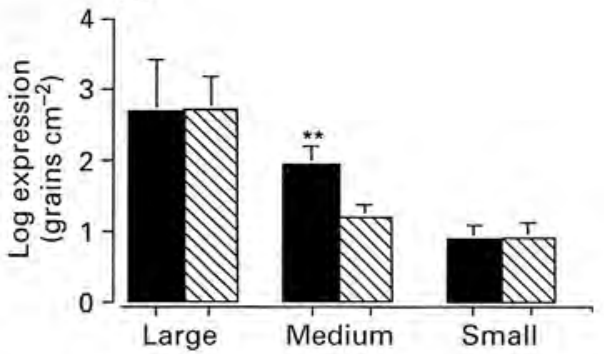

Fig. 7. Expression of mRNA, determined by in situ hybridization, for (a) cytochrome P450 aromatase and (b) the inhibin $\beta A$ subunit in the granulosal cells of large ( $>4 \mathrm{~mm})$, medium-sized $(2-4 \mathrm{~mm})$ and small $(<2 \mathrm{~mm})$ ovarian follicles of sheep with (black columns) and without (hatched columns) the $\mathrm{FecB}$ gene. Ovaries were recovered on day 4 of the oestrous cycle. Asterisks indicate significant differences $\left({ }^{* *} P<0.01\right.$; $\left.{ }^{* * *} P<0.001\right)$.

P450arom and $\beta \mathrm{A}$-subunit expression and terminal follicle development is in agreement with results from experiments in vitro. These experiments demonstrated that FSH-stimulated differentiation of granulosal cells, from small follicles, results in a dose-responsive induction of inhibin A and oestradiol (Campbell et al., 1997). Furthermore, inhibin A has been shown to modulate both oestradiol production by granulosal cells and androgen production by thecal cells in vitro (Knight, 1996; Campbell and Webb, 1995). Thus, inhibin $\beta$ A-subunit expression would appear to be an essential component of the differentiative cascade. 


\section{Conclusions}

Follicular recruitment, selection and the development of dominance involve the integration of systemic and intra-follicular mechanisms. Gonadotrophins provide the primary drive, particularly during the final stages of follicular development, although other extraovarian signals, including metabolic factors, can influence patterns of follicular growth. Indeed, it seems that, in cattle, FSH stimulates follicle growth up to $7 \mathrm{~mm}$ in diameter, followed by a requirement for LH in the final stages of follicular growth and maturation. Recent evidence on the pattern of gene expression in follicles has also demonstrated that there are a significant number of protein or peptide factors produced by follicles. The precise timing of mRNA expression, and hence production of these local factors, appears to be involved in the mechanisms of recruitment, selection and dominance. For example, it appears that a key feature in the development of follicular dominance in cows is the FSHdependent inhibition of the expression of mRNA encoding IGFBP-2 in granulosal cells. The information from these molecular studies together with results using physiologically relevant in vitro granulosal and thecal cell culture systems demonstrate that these locally produced factors can amplify, attenuate or mediate the effects of circulating gonadotrophins on granulosal and thecal cell function. The optimum integration of these control systems determines both the response of individual follicles to gonadotrophins and whether it continues to develop to become dominant or is diverted into apoptotic pathways leading to eventual atresia.

Original research presented in this review from our laboratories was supported by the Ministry of Agriculture, Fisheries and Food (MAFF), the Office of Science and Technology (OST), the European Union (EU), the Biotechnology and Biological Sciences Research Council (BBSRC), the Sino-British Friendship Scholarship Scheme (SBFSS), the National Council of Science and Technology of Mexica (CONACYT) and the British Council. The authors thank Elanco Animal Health for generously providing rGH and rIGF-1 and Hoechst Animal Health for the gift of GnRH agonist. They also thank K. J. Wood for synthesizing the IGF-II and IGF receptor probes (Fig. 5).

\section{References}

Adams GP, Matteri RL, Kastelic JP, Ko JCH and Ginther OJ (1992) Association between surges of follicle-stimulating hormone and the emergence of follicular waves in heifers Journal of Reproduction and Fertility $94177-188$

Armstrong DG and Webb R (1997) Ovarian follicular dominance: novel mechanisms and protein factors Reviezos of Reprodiction 2 139-146

Armstrong DG, Hogg CO, Campbell BK and Webb R (1996) Insulin-like growth factor (IGF) binding protein production by primary cultures of ovine granulosa and theca cells. The effect of IGF-I, gonadotropin and follicle size Biology of Reproduction 55 1163-1171

Armstrong DG, Baxter G, Gutierrez $\mathrm{CG}_{i}$ Hogg CO, Glazyrin $\mathrm{AL}$, Campbell BK, Bramley TA and Webb R (1998) Insulin-like growth factor binding protein -2 and -4 mRNA expression in bovine ovarian follicles: effect of gonadotrophins and developmental status Endocrinology 139 2146-2154

Badinga L, Driancourt MA, Savio JD, Wolfsen D, Drost M, de la Sota RL and Thatcher WW (1992) Endocrine and ovarian responses associated with the first-wave dominant follicle in cattle Biology of Reproduction 47 871-883

Bao B, Garverick HA, Smith GW, Smith MF, Salfen BE and Youngquist RS (1997a) Expression of messenger RNA encoding $3 \beta$-hydroxysteroid dehydrogenase $/ \Delta^{5}-\Delta^{*}$ isomerase during recruitment and selection of bovine ovarian follicles: identification of dominant follicles by expression of $3 \beta$-HSD mRNA within the granulosa cell layer Biology of Reproduction 56 1466-1473

Bao B, Calder MD, Xie S, Smith MF, Youngquist RS and Garverick
HA (1997b) Steroidogenic acute regulatory protein messenger ribonucleic acid (mRNA) expression is limited to theca of healthy bovine follicles Biology of Reproduction Supplement (Abstract 195)

Bao B, Garverick HA, Smith GW, Smith MF, Salfen BE and Youngquist RS (1997c) Changes in messenger RNA encoding $\mathrm{LH}$ receptor, cytochrome $\mathrm{P} 450$ side chain cleavage, and aromatase are associated with recruitment and selection of bovine ovarian follicles Biology of Reproduction 56-1158-1168

Besnard N, Pisselet C, Monniaux D, Locatelli A, Benne E, Gasser E, Hatey F and Monget P (1996) Expression of messenger ribonucleic acids of insulin-like growth factor binding proteins $-2,-4$ and -5 in the ovine ovary: localization and changes during growth and atresia of antral follicles Biology of Reproduction 55 1356-1367

Bodensteiner KJ, Wiltbank MC, Bergfelt DR and Ginther OJ (1996) Alterations in follicular estradiol and gonadotropin receptors during development of bovine antral follicles Theriogenology 45 499-512

Campbell BK and Webb R (1995) Evidence that inhibin has paracrine and autocrine actions in controlling ovarian function in sheep Journal of Reproduction and Fertility Abstract Series 15 Abstract 140

Campbell BK, Baird DT, McNeilly AS and Scaramuzzi RJ (1990) Ovarian secretion rates and peripheral concentrations of inhibin in normal and androstenedione-immune ewes with an autotransplanted ovary Joumal of Endocrinology $127285-296$ 
Campbell BK, Scaramuzzi RJ and Webb R (1995) Control of antral follicle development and selection in sheep and cattle Journal of Reproduction and Fertility Supplement 49.335-350

Campbell BK Scaramuzzi RJ and Webb R (1996) Induction and maintenance of oestradiol and immunoreactive inhibin production with FSH by ovine granulosa cells cultured in serum free media fournal of Reproduction and Fertility 106 7-16

Campbell BK Groome N and Baird DT (1997) Effect of dose and time of exposure to FSH on oestradiol and dimeric inhibin A production by undifferentiated ovine granulosa cells in serum-free culture Journal of Reproduction and Fertility Abstract Series 19 Abstract 32

Campbell BK, Baird DT and Webb R (1998a) Effects of dose of $\mathrm{LH}$ on androgen production and luteinization of ovine theca cells cultured in a serum-free system Journal of Reproduction and Fertility 112 69-77

Campbell BK Dobson H and Scaramuzzi RJ (1998b) Ovarian function in ewes made hypogonadal with GnRHantagonist and stimulated with FSH in the presence or absence of low amplitude LH pulses Journal of Endocrinology 156 213-222

Cohick WS, Armstrong JD, Withacre MD, Lucy MC, Harvey RW and Campbell RM (1996) Ovarian expression of insulin-like growth factor- $\mathrm{T}$ (IGF-I), IGF binding proteins and growth hormone $(\mathrm{GH})$ receptor in heifers actively immunized against GH-releasing factor Endocrinology 137 1670-1677

de la Sota RL, Lucy RL, Staples CR and Thatcher WW (1993) Effects of recombinant bovine somatotropin (Sometribove) on ovarian function in lactating and nonlactating dairy cows Journal of Dairy Science 76 1002-1013

Driancourt MA, Webb R and Fry RC (1991) Does follicular dominance occur in ewes? lournal of Reproduction and Fertility 93 63-70

Eckery DC, Tisdall, DJ, Heath DA and McNatty KP (1996) Morphology and function of the ovary during fetal and early neonatal life: comparison between the sheep and brushtail possum (Trichosumus oulpecula) Animal Reproduction Science $421-4$

Evans ACO and Fortune JE (1997) Selection of the dominant follicle in cattle occurs in the absence of differences in the expression of messenger ribonucleic acid for gonadotropin receptors Endoctinology 138 2963-2971

Ginther OJ, Wiltbank MC, Fricke PM, Gibbons JR and Kot K (1996) Selection of the dominant follicle in cattle Biology of Reproduction 55 1187-1194

Gong JG, Bramley TA and Webb R (1991) The effect of recombinant bovine somatotrophin on ovarian function in heifers: follicular populations and peripheral hormones Biology of Reproduction 45 941-949

Gong JG, Bramley TA and Webb R (1993) The effect of recombinant bovine somatotrophin on ovarian follicular growth and development in heifers Journal of Reproduction and Fertility $97247-254$

Gong JG, Bramley TA, Gutierrez CG, Peters AR and Webb R (1995) Effects of chronic treatment with a gonadotrophinreleasing hormone agonist on peripheral concentrations of FSH and $\mathrm{LH}$, and ovarian function in heifers journal of Reproduction and Fertility 105 263-270

Gong JG, Campbell BK, Bramley TA, Gutierrez CG, Peters AR and Webb R (1996) Suppression in the secretion of folliclestimulating hormone and luteinizing hormone, and ovarian follicle development in heifers continuously infused with a gonadotropin-releasing hormone agonist Biology of Reproduction 55 68-74
Gong JG, Campbell BK and Webb R (1997) Stimulation of ovarian follicles to the preovulatory size by infusion with FSH alone in GnRH-agonist-treated heifers Journal of Reproduction and Fertility Abstract Series 19 Abstract 162

Gutierrez CG, Ralph JH, Wilmut I and Webb R (1997a) Follicle growth and antrum formation of bovine preantral follicles in long-term in vitro culture Journal of Reproduction and Fertility Abstract Series 19 Abstract 31

Gutierrez CG, Oldham J, Bramley TA, Gong JG, Campbell BK and Webb R (1997b) The recruitment of ovarian follicles is enhanced by increased dietary intake in heifers Journal of Animal Science 75 1876-1884

Gutierrez CG, Campbell BK, Armstrong DG and Webb R (1997c) Insulin-like growth factor-I (IGI-I) production by bovine granulosa cells in titro and peripheral IGF-I measurement in cattle serum: an evaluation of IGEBP extraction protocols Journal of Endocrinology 153 231-240

Gutierrez CG, Campbell BK and Webb R (1997d) Development of a long-term bovine granulosa cell culture system: induction and maintenance of estradiol production, response to follicle-stimulating hormone, and morphological characteristics Biology of Reproduction 56 608-616

Knight PG (1996) Roles of inhibins, activins and follistatin in the female reproductive system Frontiers of Neuroendocrinology $17476-509$

Leeuwenberg BR, Hurst PR and McNatty KP (1995) Expression of IGF-I mRNA in the oxine ovary Journal of Molecular Endocrinology 15 251-258

Lucy MC, Collier RJ, Kitchell ML, Dibner JJ, Hauser SD and Krivi GG (1993) Immunohistochemical and nucleic acid analysis of somatotropin receptor populations in the bovine ovary Biology of Reproduction 48 1219-1227

Mason HD, Wills D, Holly JMP, Cwyfan-Hughs SC, Seppala M and Franks S (1992) Inhibitory effects of insulin-like growth factor-binding proteins on steroidogenesis by human granulosa cells in culture Molecular and Cellular Endocrinology $89 \mathrm{R} 1-\mathrm{R} 4$

Monget P, Monniaux D, Pisselet C and Durand P (1993) Changes in insulin-like growth factor-I (IGF-1), IGF-II and their binding proteins during growth and atresia of ovine ovarian follicles Endocrinology 132 1438-1446

Perks CM, Denning-Kendall PA, Gilmour RS and Wathes DC (1995) Localization of messenger ribonucleic acids for insulin-like growth factor I (IGF-I), IGF-II and the type 1 IGF receptor in the ovine ovary throughout the estrous cycle Endocrinology 136 5266-5273

Ralph JH, Wilmut 1 and Telfer EE (1995) In vitro growth of bovine preantral follicles and the influence of FSH on follicular oocyte diameters Journal of Reproduction and Fertility Abstract Series 15 Abstract 12

Ravindra JP and Rawlings NC (1997) Ovarian follicular dynamics in ewes during the transition from anoestrus to the breeding season Joumial of Reproduction and Fertility $110279-289$

Roberts AJ and Skinner MK (1991) Transforming grow th factor$\alpha$ and $-\beta$ differentially regulate growth and steroidogenesis of bovine thecal cells during antral follicle development Endocrinology 129 2041-2048

Schrick FN, Surface RA, Pritchard JY, Dailey RA, Townsend EC and Inskeep EK (1993) Ovarian structures during the estrous cycle and early pregnancy in ewes Biology of Reproduction $491133-1140$

Segaloff DL, Wang H and Richards JS (1990) Hormonal regulation of luteinizing hormone/chorionic gonadotropin receptor mRNA in rat ovarian cells during follicular 
development and luteinization Molecular Endocrinology 4 1856-1865

Sirois J and Fortune JE (1990) Lengthening the bovine estrous cycle with low levels of exogenous progesterone: a model for studying ovarian follicular dominance Endocrinology 127 916-925

Skyer DM, Garverick HA, Youngquist RS and Krause GF (1987) Ovarian follicular populations and in vitro steroidogenesis on three different days of the bovine estrous cycle Journal of Animal Science $641710-1716$

Souza CJH, Campbell BK and Baird DR (1996) Follicular dynamics and ovarian steroid secretion in sheep during anoestrus Journal of Reproduction and Fertility 108 101-106

Souza CJH, Campbell BK and Baird DT (1997a) Follicular dynamics and ovarian steroid secretion in sheep during the follicular and early luteal phases of the estrous cycle Biology of Reproduction $56483-488$

Souza CJH, Campbell BK, Baird DT and Webb R (1997b) Secretion of inhibin A and follicular dynamics throughout the estrous cycle in sheep with and without the Booroola gene (Fec $\beta$ ) Endocrinology 138 5333-5340

Souza CJH, Campbell BK and Baird DT (1998) Follicular development and concentrations of ovarian steroids and inhibin A in jugular venous plasma during the luteal phase of the Destrous cycle lournal of Endocrinology 156 563-572

Spicer LJ, Stewart RC, Avarey P, Francisco CC and Keefer BE (1997) Insulin-like growth factor-binding protein-2 and -3 ; their biological effects in bovine thecal cells Biology of Reproduction 56 1458-1465

Tian XC, Berndtson AK and Fortune JE (1995) Differentiation of bovine preovulatory follicles during the follicular phase is associated with increases in messenger ribonucleic acid for cytochrome $\mathrm{P} 450$ side-chain cleavage, $3 \beta$-hydroxysteroid dehydrogenase, and P450 17a-hydroxylase, but not P450 aromatase Endocrinology $1365102-5110$

Wandji SA, Srsen V, Voss AK, Eppig J and Fortune JE (1996) Initiation in vitro of growth of bovine primordial follicles Biology of Reproduction $\mathbf{5 5 9 4 2 - 9 4 8}$

Webb R and Armstrong DG (1998) Control of ovarian function; effect of local interactions and environmental influences on follicular turnover in cattle: a review Livestock Production Science 53 95-112

Webb R and Gauld IK (1987) Endocrine control of follicular growth in the ewe. In Follicular Growth and Ovulation Rate in Farm Animals pp 107-118 Eds JF Roche and D O'Callaghan. Martinus Nijhoff, Dordrecht

Xu ZZ, Garverick HA, Smith GW, Smith MF, Hamilton SA and Youngquist RS (1995a) Expression of follicle-stimulating hormone and luteinizing hormone receptor messenger ribonucleic acids in bovine follicles during the first follicular wave Biology of Reproduction 53 951-957

Xu ZZ, Garverick HA, Smith GW, Smith MF, Hamilton SA and Youngquist RS (1995b) Expression of messenger RNA encoding cytochrome $\mathrm{P} 450$ side-chain cleavage, cytochrome P450 17 $\alpha$-hydroxylase and cytochrome P450 aromatase in bovine follicles during the first follicular wave Endocrinology 136 981-989

Yuan W, Bao B, Garverick HA, Youngquist RS and Lucy MC (1998) Follicular dominance in cattle is associated with divergent patterns of ovarian gene expression for insulin-like growth factor (IGF) -I, IGF-II and IGF binding protein-2 in dominant and subordinate follicles Domestic Animal Endocrinology 15 55-63 